\title{
Role Of Mesiodens In The Etiology Of Midline Diastema
}

Faazila Fathima ${ }^{1}$, Harish Babu S ${ }^{2 *}$, Senthil Murugan $\mathrm{P}^{3}$

${ }^{1}$ Saveetha Dental College and Hospitals, Saveetha Institute of Medical and Technical Sciences, Saveetha University, Chennai, India.

${ }^{2}$ Professor, Department of Orthodontics, Saveetha Dental College and Hospitals, Saveetha Institute of Medical and Technical Sciences, Saveetha University, Chennai, 600077, India.

${ }^{3}$ Associate Professor, Department of Oral Surgery, Saveetha Dental College and Hospitals, Saveetha Institute of Medical and Technical Sciences, Saveetha University, Chennai, 600077, India.

\section{Abstract}

Midline diastema is a space between the maxillary or mandibular central incisors. It can be due to various etiology such as genetic, environmental, and so on. Mesiodens which is a supernumerary tooth located in the maxillary central incisor region, is said to be one of the causes of midline diastema.However its role in the etiology of midline diastema is not well known. The presence of diastema in the patients has esthetics and malocclusion concerns. Correct diagnosis of the etiology of diastema is essential for successful treatment.The aim of this study is to evaluate the prevalence of mesiodens in patients with midline diastema.Digital records of 1000 orthodontic patients over a six month period were retrieved and screened for presence of midline diastema.285 patient records with midline diastema as a clinical finding were randomly selected and included in the study. Data on age, gender and presence or absence of mesiodens was methodically tabulated in Excel sheets and imported in SPSS and analyzed. Pearson's test of independence was done to check for association between the variables.From this study, it was observed that mesiodens was present only in $9 \%$ of the patients with midline diastema. Mesiodens was observed predominantly in males than in females in the age group of 10 to 18 years. In the Pearson's Chi Square test $\mathrm{p}$ value was 0.00 among different age groups $(\mathrm{P}<0.05$ statistically significant). Among the genders Pearson's Chi Square test $\mathrm{p}$ value was $0.014(\mathrm{P}<0.05$ statistically significant $)$. Within the limits of the study, it can be concluded that the role of mesiodens in the etiology of midline diastema was not significant. There was statistically significant association between age, gender and presence of mesiodens. Males showed more prevalence of mesiodens than females. Mesiodens was observed more commonly in the younger age group.

Keywords: Midline Diastema; Mesiodens; Orthodontic Treatment; Prevalence.

\section{Introduction}

Aesthetics and function are the two most important goals of modern-day dentistry [1-3]. Maxillary midline diastema is one of the most frequently seen malocclusions.Andrews described the dental midline diastema as a rather common form of incomplete occlusion characterized by a space between the maxillary and less frequently the mandibular central incisors [4].

Midline diastema is generally considered a part of normal dental development during mixed dentition period, which will be self corrected after eruption of maxillary canine [5, 6]. However midline diastema unrelated to the eruption of teeth has been observed owing to various etiological factors such as supernumerary teeth, congenital absence of permanent teeth, deleterious oral health high frenal attachment and others [7, 8]. Treating the midline diastema is a problem for the dental practitioner as many different aetiologies are reported to be associated with it [9].

Teeth which are in excess from the normal number are known as supernumerary teeth $[10,11]$. The supernumerary teeth when located in the maxillary central incisor region are called as mesiodens [12]. Their prevalence has been estimated to be 0.15 to $2.2 \%$ of the population with a predilection for males [13]. The most common type of supernumerary tooth is mesiodens. It can be single or multiple in an arch. The presence of a mesiodens is usually found to be impacted, with a conical crown and a single root [14]. The diagnosis of the mesiodens is made by clinical and radiographic examinations.

\footnotetext{
*Corresponding Author:

Harish Babu S,

Professor, Department of Orthodontics, Saveetha Dental College and Hospitals, Saveetha Institute of Medical and Technical Sciences, Saveetha University, Chennai, 600077, India. Tel: +919360575950

E-mail: harish.ortho@gmail.com
}

Received: September 06, 2020

Accepted: October 09, 2020

Published: October 24, 2020

Citation: Faazila Fathima, Harish Babu S, Senthil Murugan P. Role Of Mesiodens In The Etiology Of Midline Diastema. Int J Dentistry Oral Sci. 2020;7(10):888-891. doi: http:// dx.doi.org/10.19070/2377-8075-20000176

Copyright: Harish Babu S ${ }^{\circ} 2020$. This is an open-access article distributed under the terms of the Creative Commons Attribution License, which permits unrestricted use, distribution and reproduction in any medium, provided the original author and source are credited. 
Evidence regarding etiology of mesiodens indicates that genetic susceptibility together with environmental factors might increase the activity of dental lamina leading to formation of the extra tooth $[15,16]$. Extraction of mesiodens in the early mixed dentition helps spontaneous alignment of the adjacent teeth [17].

Clinician's knowledge of common anomalies and their location in the primary and mixed dentition will result in early diagnosis and may consequently prevent further complications [18]. Therefore, this study was conducted to evaluate the prevalence of mesiodens in patients reporting with midline diastema.

\section{Materials and Method}

\section{Study Setting}

This study was based on data collected from the digital database of Saveetha Dental College and Hospitals. From 86000 patient records over a six month period from September 2019 to February 2020, 1000 records of patients reporting with Orthodontic complaints was retrieved. Approval was obtained from the institutional Scientific Review Board and ethical committee.The ethical approval number for the present study is SDC/SIHEC/2020/ DIASDATA/0619-0320. Two examiners were included in the study.

\section{Sampling}

Data was collected retrospectively over a six month period spanning from September 2019 to February 2020. A total of 1000 case sheets of patients were reviewed. Cross verification of data for error was done by presence of additional reviewer and by photographic evaluation. Simple random sampling was done to minimize sampling bias. 1000 case records were screened for clinical finding of mesiodens using appropriate filters. The final sample size was 285 patients with midline diastema.

\section{Data collection}

The data was entered in the system in a methodical manner. For the present study, Clinical examination, radiographic examination, orthodontic diagnosis and photographs of these patients were evaluated to find the presence of midline diastema and mesiodens. The data was entered in excel manually and imported to SPSS for analysis. Incomplete or censored data was excluded from the study.

\section{Analytics}

IBM SPSS Software was used for data analysis. Descriptive statistics which included frequency of distribution and Pearson's Chi Square test was used for analysis. $\mathrm{p}<0.05$ was considered statistically significant.

\section{Results and Discussion}

Incidence of mesiodens in the study population was less. Age group of 10-18 years and 19-35 years showed more prevalence of mesiodens which accounted to $37.5 \%$ and $9.4 \%$ of the patients with midline diastema (figure 1). Mesiodens was present predominantly in males than females.It was observed that out of 178 males, mesiodens was present in $12.4 \%$ and absent in $87.6 \%$ and out of 107 females, mesiodens was present in $3.7 \%$ and absent in $96.3 \%$ (figure 2). Mesiodens was noted in only $9.3 \%$ of the patients with midline diastema while the rest of $90.8 \%$ was due to other etiologies (figure 3). Chi square test was done to test for association between age and mesiodens. Association was found to be statistically significant. Pearson's Chi Square $\mathrm{p}$ value was 0.00 hence proving that association of mesiodens among midline diastema patients in different age groups is statistically significant $(\mathrm{P}<0.05)$. Chi square test was done to test for association between gender and mesiodens and the association was found to be statistically significant. Pearson's Chi Square p value was 0.014 hence proving that association of mesiodens among male and female midline diastema patients is statistically significant $(\mathrm{P}<0.05)$.

In this study, it was observed that only $9 \%$ of the patients with midline diastema had presence of mesiodens. Also, mesiodens showed more prevalence in males in the younger age group. Campbell et al., stated that midline diastema could be transient or created by developmental, pathological or iatrogenic factors [19]. .Treatment of diastema varies and it requires correct diagnosis of its etiology and early intervention relevant to the specific etiology. Correct diagnoses includes medical and dental history, radiological and clinical examination and possibly tooth size evaluation $[20$, 21].

Figure 1. Bar graph depicts the association between age and mesiodens. $X$ axis denotes age group and $Y$ axis denotes the number of midline diastema patients who have and do not have mesiodens. It shows that highest prevalence of mesiodens was observed in the age group of 10-18years.Pearson's Chi Square value was $\mathbf{0 . 0 0}$ hence proving that association of mesiodens among midline diastema patients in different age groups is statistically significant $(\mathbf{P}<0.05)$.

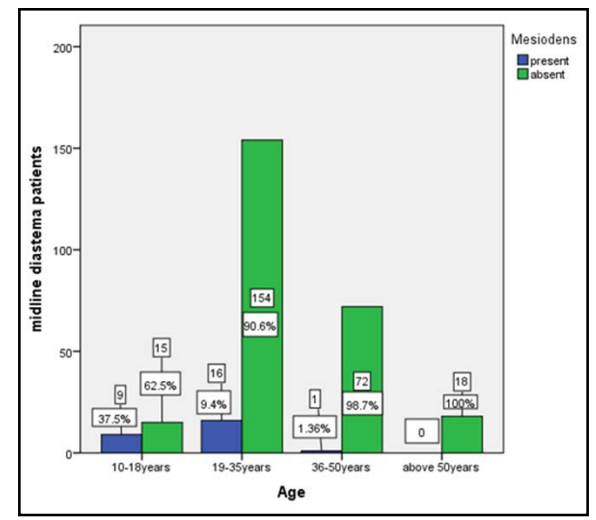


Figure 2. Bar graph depicts the association between gender and mesiodens. $\mathrm{X}$ axis denotes gender and $\mathrm{Y}$ axis denotes the number of midline diastema patients who have and do not have mesiodens.Males showed more prevalence of mesiodens compared to females. This was found to be statistically significant. Pearson's Chi Square value,$p=0.014$. $(P<0.05)$. Hence Mesiodens associated midline diastema is more common among males.

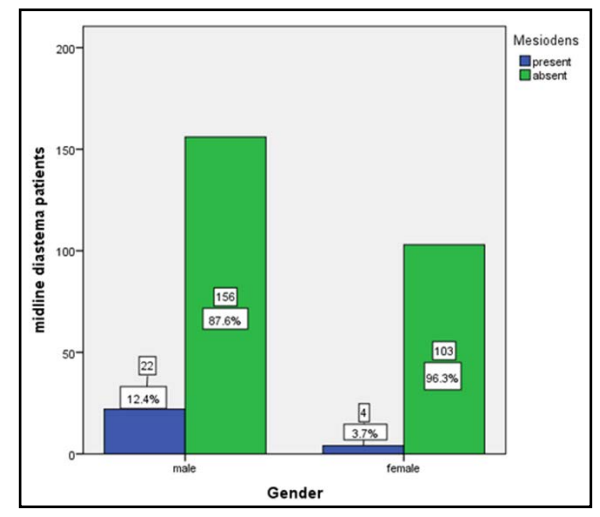

Figure 3. Bar graph represents the distribution of mesiodens among midline diastema patients. $\mathrm{X}$ axis denotes mesiodens and $\mathrm{Y}$ axis denotes the number of midline diastema patients. Blue colour denotes presence of mesiodens and green colour denotes absence of mesiodens. This shows that out of 285 patients,mesiodens was present in $9.1 \%$ and absent in $90.8 \%$ of the individuals with midline diastema.

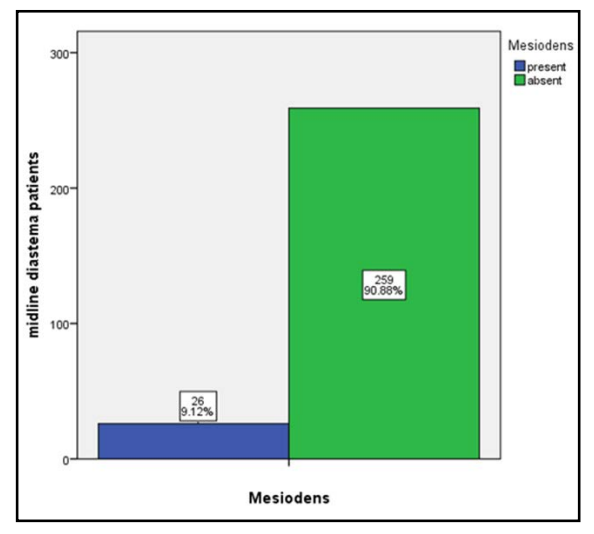

Studies done by Asaumi et al [22], Ersin et al., [23] and kim et al., [24] reported that the prevalence of mesiodens varies from 0.15 to $7.8 \%$, with a higher prevalence in males, with a proportion of $2: 1$, which was similar to the present study.Lara et al, observed that $28.57 \%$ of mesiodens was associated with midline diastema [25].

Studies by Hurlen et al., [26] and Salcido-García et al., [27] observed the prevalence of mesiodens among their study population of orthodontic patients with dental anomalies to be $1.4 \%$ and $1.6 \%$ respectively. Yamaoka et al stated that although the literature associates mesiodens as etiological factor to midline diastema, the presence of both situations in the same patient is very uncommon [28].

Similar to the results of the present study, various other studies also found the prevalence of mesiodens predominantly in males with the ratio being 1.5:1 [29, 30] Sexual differences in the prevalence of mesiodens disagreed with what has been found for tooth agenesis. Tooth agenesis is more frequent among females [31].

As in this study, mesiodens was commonly observed in younger individuals,Kazanci $\mathrm{F}$ et al also reported increased prevalence of mesiodens younger age group [32]. In case of asymmetry, mesiodens should be suspected [33]. In primary dentition, mesiodens often have normal shape and erupt normally and this is the reason why these teeth are often overlooked.
Management of mesiodens depends on the type and position of the tooth. Immediate removal of mesiodens is usually indicated [34]. Munns [35] stated that the earlier the mesiodens is removed, the better the prognosis.

The most preferred treatment for midline diastema due to mesiodens is the surgical removal of the mesiodens followed by the orthodontic space closure [36]. Interestingly, after the mesiodens removal, there will be 1 to $1.5 \mathrm{~mm}$ reduction in the diastema [37]. Spilka and Mathews stated that relapse is a major concern in the correction of midline diastema [38].

Exact diagnosis and removal of the aetiology is the key to obtaining a stable result in treatment of midline diastema. The present study however has certain limitations since it studies the prevalence in a limited demography of patients only reporting to a Dental hospital.

\section{Conclusion}

Within the limits of the study, it can be concluded that the role of mesiodens in the etiology of midline diastema was not significant. There was a statistically significant association between age, gender and presence of mesiodens.Males in the younger age group showed more prevalence of mesiodens than females. 


\section{Acknowledgment}

This research was supported by Saveetha Dental College and Hospital. We thank the department of Orthodontics, Saveetha Dental College for providing insight and expertise that greatly assisted this research.

\section{References}

[1]. Hamdan AM, Al-Omari IK, Al-Bitar ZB. Ranking dental aesthetics and thresholds of treatment need: a comparison between patients, parents, and dentists. Eur J Orthod. 2007 Aug; 29(4): 366-71. PMID: 17702796.

[2]. Sivamurthy G, Sundari S. Stress distribution patterns at mini-implant site during retraction and intrusion--a three-dimensional finite element study. Prog Orthod. 2016; 17: 4. PMID: 26780464.

[3]. Samantha C, Sundari S, Chandrasekhar S, Sivamurty G, Dinesh S. Comparative Evaluation of Two Bis-GMA Based Orthodontic Bonding Adhesives - A Randomized Clinical Trial. J Clin Diagn Res. 2017 Apr; 11(4): ZC40ZC44. PMID: 28571259.

[4]. Andrews LF. The six keys to normal occlusion. Am J Orthod. 1972 Sep; 62(3): 296-309. PMID: 4505873

[5]. Krishnan S, Pandian S, Kumar S A. Effect of bisphosphonates on orthodontic tooth movement-an update. J Clin Diagn Res. 2015 Apr; 9(4): ZE01-5. PMID: 26023659

[6]. Kamisetty SK, Verma JK, Arun, Sundari S, Chandrasekhar S, Kumar A. SBS vs Inhouse Recycling Methods-An Invitro Evaluation. J Clin Diagn Res. 2015 Sep; 9(9): ZC04-8. PMID: 26501002.

[7]. Jain RK, Kumar SP, Manjula WS. Comparison of intrusion effects on maxillary incisors among mini implant anchorage, j-hook headgear and utility arch. J Clin Diagn Res. 2014 Jul; 8(7): ZC21-4. PMID: 25177631.

[8]. Felicita AS. Orthodontic management of a dilacerated central incisor and partially impacted canine with unilateral extraction - A case report. Saudi Dent J. 2017 Oct; 29(4): 185-193. PMID: 29033530.

[9]. Kamath MK, Arun AV. Midline diastema. International Journal of Orthodontic Rehabilitation. 2016 Jul 1; 7(3): 101.

[10]. Rohilla M. Mesiodens Diagnosis and Management: Series of Case Reports. 2018.

[11]. Vikram NR, Prabhakar R, Kumar SA, Karthikeyan MK, Saravanan R. Ball Headed Mini Implant. J Clin Diagn Res. 2017 Jan; 11(1): ZL02-ZL03. PMID: 28274084

[12]. Rubika J, Felicita AS, Sivambiga V. Gonial angle as an indicator for the prediction of growth pattern. World J Dent. 2015; 6(3): 161-3.

[13]. Gündüz K, Celenk P, Zengin Z, Sümer P. Mesiodens: a radiographic study in children. J Oral Sci. 2008 Sep; 50(3): 287-91. PMID: 18818464.

[14]. Mukhopadhyay S. Mesiodens: a clinical and radiographic study in children. J Indian Soc Pedod Prev Dent. 2011 Jan-Mar; 29(1): 34-8. PMID: 21521916.

[15]. Felicita AS. Quantification of intrusive/retraction force and moment generated during en-masse retraction of maxillary anterior teeth using miniimplants: A conceptual approach. Dental Press J Orthod. 2017 Sep-Oct; 22(5): 47-55. PMID: 29160344

[16]. Felicita AS, Chandrasekar S, Shanthasundari KK. Determination of craniofacial relation among the subethnic Indian population: a modified approach - (Sagittal relation). Indian J Dent Res. 2012 May-Jun; 23(3): 30512. PMID: 23059564

[17]. Ramesh Kumar KR, Shanta Sundari KK, Venkatesan A, Chandrasekar S. Depth of resin penetration into enamel with 3 types of enamel conditioning methods: a confocal microscopic study. Am J Orthod Dentofacial Orthop. 2011 Oct; 140(4): 479-85. PMID: 21967934

[18]. Viswanath A, Ramamurthy J, Dinesh SP, Srinivas A. Obstructive sleep apnea: awakening the hidden truth. Niger J Clin Pract. 2015 Jan-Feb; 18(1):
1-7. PMID: 25511335.

[19]. Campbell PM, Moore JW, Matthews JL. Orthodontically corrected midline diastemas. A histologic study and surgical procedure. Am J Orthod. 1975 Feb; 67(2): 139-58. PMID: 1054215.

[20]. Huang WJ, Creath CJ. The midline diastema: a review of its etiology and treatment. Pediatr Dent. 1995 May-Jun; 17(3): 171-9. PMID: 7617490.

[21]. Pandian KS, Krishnan S, Kumar SA. Angular photogrammetric analysis of the soft-tissue facial profile of Indian adults. Indian J Dent Res. $2018 \mathrm{Mar}-$ Apr; 29(2): 137-143. PMID: 29652003.

[22]. Asaumi JI, Shibata Y, Yanagi Y, Hisatomi M, Matsuzaki H, Konouchi H,et al. Radiographic examination of mesiodens and their associated complications. Dentomaxillofac Radiol. 2004 Mar; 33(2): 125-7. PMID: 15314006

[23]. Ersin NK, Candan U, Alpoz AR, Akay C. Mesiodens in primary, mixed and permanent dentitions: a clinical and radiographic study. J Clin Pediatr Dent. 2004 Summer; 28(4): 295-8. PMID: 15366615

[24]. Choi KM, Lee J, Kim YH, Kim KB, Kim DL, Kim SG, et al. Relation between insulin resistance and hematological parameters in elderly KoreansSouthwest Seoul (SWS) Study. Diabetes Res Clin Pract. 2003 Jun; 60(3): 205-12. PMID: 12757983.

[25]. Lara TS, Lancia M, da Silva Filho OG, Garib DG, Ozawa TO. Prevalence of mesiodens in orthodontic patients with deciduous and mixed dentition and its association with other dental anomalies. Dental Press J Orthod. 2013 Nov-Dec; 18(6): 93-9. PMID: 24351155.

[26]. Hurlen B, Humerfelt D. Characteristics of premaxillary hyperodontia. A radiographic study. Acta Odontol Scand. 1985 May; 43(2): 75-81. PMID: 3863448.

[27]. Ledesma-Montes C, Garcés-Ortíz M, Salcido-García JF, Hernández-Flores F. Study on frequency of dental developmental alterations in a Mexican school-based population. Med Oral Patol Oral Cir Bucal. 2016 May 1; 21(3): e316-20. PMID: 26946196.

[28]. Yamaoka M, Furusawa K, Yasuda K. Effects of maxillary anterior supernumerary impacted teeth on diastema. Oral Surg Oral Med Oral Pathol Oral Radiol Endod. 1995 Sep; 80(3): 252. PMID: 7489264.

[29]. Tyrologou S, Koch G, Kurol J. Location, complications and treatment of mesiodentes--a retrospective study in children. Swed Dent J. 2005; 29(1): 1-9. PMID: 15898358.

[30]. von Arx T. Anterior maxillary supernumerary teeth: a clinical and radiographic study. Aust Dent J. 1992 Jun; 37(3): 189-95. PMID: 1627067.

[31]. Garib DG, Peck S, Gomes SC. Increased occurrence of dental anomalies associated with second-premolar agenesis. Angle Orthod. 2009 May; 79(3): 436-41. PMID: 19413376.

[32]. Kazanci F, Celikoglu M, Miloglu O, Yildirim H, Ceylan I. The frequency and characteristics of mesiodens in a Turkish patient population. Eur J Dent. $2011 \mathrm{Jul} ; 5(3): 361-5$. PMID: 21769282.

[33]. Rajab LD, Hamdan MA. Supernumerary teeth: review of the literature and a survey of 152 cases. Int J Paediatr Dent. 2002 Jul;12(4):244-54. PMID: 12121534.

[34]. Felicita AS. Orthodontic extrusion of Ellis Class VIII fracture of maxillary lateral incisor - The sling shot method. Saudi Dent J. 2018 Jul; 30(3): 265269. PMID: 29942113.

[35]. Munns D. Unerupted incisors. Br J Orthod. 1981 Jan; 8(1): 39-42. PMID: 6944106.

[36]. Dinesh SP, Arun AV, Sundari KK, Samantha C, Ambika K. An indigenously designed apparatus for measuring orthodontic force. J Clin Diagn Res. 2013 Nov; 7(11): 2623-6. PMID: 24392423.

[37]. Khandelwal V, Nayak AU, Naveen RB, Ninawe N, Nayak PA, Sai Prasad SV. Prevalence of mesiodens among six- to seventeen-year-old school going children of Indore. J Indian Soc Pedod Prev Dent. 2011 Oct-Dec; 29(4): 288-93. PMID: 22016311.

[38]. Spilka CJ, Mathews PH. Surgical closure of diastema of central incisors. Am J Orthod. 1979 Oct; 76(4): 443-7. PMID: 291344. 